\title{
Synthesis of conformationally restricted glutamate and glutamine derivatives from carbonylation of orthopalladated phenylglycine derivatives
}

\author{
Esteban P. Urriolabeitia*, Eduardo Laga and Carlos Cativiela
}

\section{Full Research Paper}

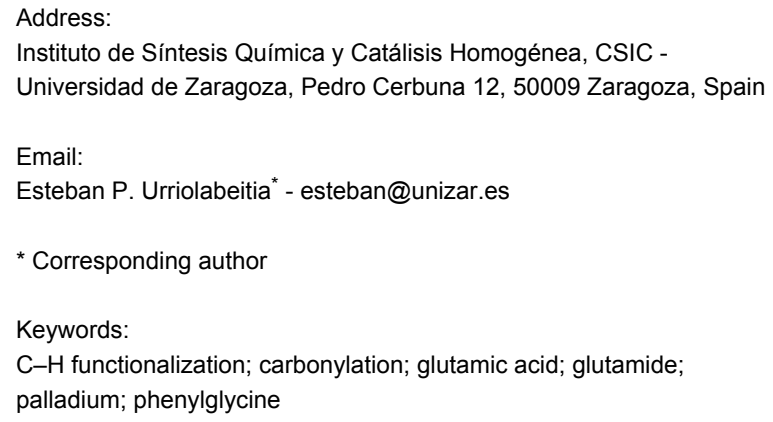

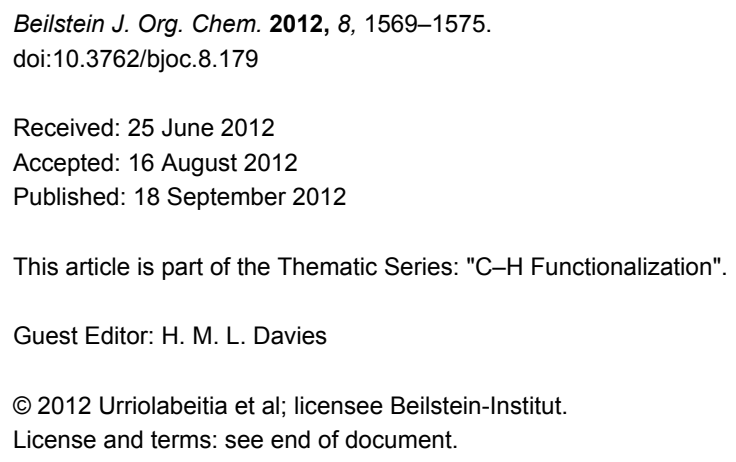

\begin{abstract}
A new method for the regioselective synthesis of 2-alkoxycarbonyl- and 2-(aminocarbonyl)phenylglycinate methyl esters has been developed. The reaction of the orthopalladated complex $\left[\mathrm{Pd}(\mu-\mathrm{Cl})\left(\mathrm{C}_{6} \mathrm{H}_{4}\left(\mathrm{CH}\left(\mathrm{CO}_{2} \mathrm{Me}\right) \mathrm{NMe}_{2}\right)-2\right)\right]_{2}$ (1) with nucleophiles $\mathrm{HNu}$ under a $\mathrm{CO}$ atmosphere results in the selective incorporation of the $\mathrm{C}(\mathrm{O}) \mathrm{Nu}$ moiety to the phenyl ring and formation of the carbonyl species ortho- $\mathrm{C}_{6} \mathrm{H}_{4}(\mathrm{C}(\mathrm{O}) \mathrm{Nu})\left(\mathrm{CH}\left(\mathrm{CO}_{2} \mathrm{Me}\right) \mathrm{NMe}_{2}\right)(\mathbf{2} \mathbf{a}-\mathbf{j})\left(\mathrm{Nu}=\mathrm{OR}, \mathrm{NHR}, \mathrm{NR}_{2}\right)$. Compounds $\mathbf{2} \mathbf{a}-\mathbf{j}$ are conformationally restricted analogues of glutamic acid and glutamine and are interesting due to their biological and pharmacological properties. The reaction of $\left[\mathrm{Pd}(\mu-\mathrm{Cl})\left(\mathrm{C}_{6} \mathrm{H}_{4}\left(\mathrm{CH}\left(\mathrm{CO}_{2} \mathrm{Me}\right) \mathrm{NHTf}\right)-2\right)\right]_{2}(3)$ with nucleophiles in a $\mathrm{CO}$ atmosphere results, however, in the formation of the cyclic isoindolinone or the open 2-carboxyphenylglycine methyl esters, with the reaction outcome being driven by the choice of the solvent.
\end{abstract}

\section{Introduction}

The selective functionalization of organic molecules is, at the present time, one of the most developed areas of organic and organometallic chemistry. Several factors have contributed to this spectacular growth. The main one is the use of transition metals, such as Rh, Ru, Pd, Pt or Au, with the capability of activating and breaking $\mathrm{C}-\mathrm{H}$ bonds and, thus, transforming the inert $\mathrm{C}-\mathrm{H}$ unit into the reactive $\mathrm{C}-\mathrm{M}$ group $(\mathrm{M}=$ transition metal) [1-3]. In addition, the introduction of the concept of a "directing group" enables the attack of the metal on a unique position [4], therefore affording highly selective processes and avoiding the obtainment of unwanted isomers.

Probably the aspect of this method of synthesis with the greatest impact is the oxidative coupling of two $\mathrm{C}-\mathrm{H}$ bonds to give a new $\mathrm{C}-\mathrm{C}$ bond, because it avoids the use of prefunctionalized substrates, minimizes the amount of waste generated during the reaction and, in general, allows for the reactions to occur under mild conditions and tolerates a variety of functional groups 
[5-10]. This is advantageous when reactive or sensitive fragments are present in the molecular scaffold.

We are interested in the regioselective functionalization of $\alpha$-amino acids [11-13], due to the extraordinary interest in these delicate molecules as building blocks of peptides and proteins, and because of their relevant biological activity. In this context, we have recently reported $\mathrm{C}-\mathrm{H}$ bond activation processes on a variety of arylglycines substituted at the phenyl ring, and the corresponding synthesis of a new family of orthopalladated complexes [12]. The carbonylation of these compounds allows for a general synthesis of methyl $(1 H)$-isoindolin-1-one-3carboxylates under very mild reaction conditions, regardless of whether the substituents at the aryl ring $\mathrm{R}_{n}$ are electron-withdrawing or electron-releasing. This method, shown in Scheme 1, represents a real synthetic alternative to other classical preparative pathways [12].

$$
\text { methyl (1H)-isoindolin-1-one-3-carboxylates }
$$

Scheme 1: Synthesis of methyl $(1 H)$-isoindolin-1-one-3-carboxylates by carbonylation of phenylglycine derivatives [12].

With the aim of expanding the scope of application of this method, we report in this paper the results obtained when other functional groups on the same starting material (methyl phenylglycinate) are changed. In particular, we have detected that the presence of different types of substituents at the nitrogen atom has a critical effect on the final outcome of the reaction and that, instead of the expected $(1 H)$-isoindolin-1-ones, conformationally restricted glutamines and glutamates can be obtained. The undoubted importance of conformationally constrained aminoacids is based on the fact that their incorporation into peptides constitutes a very useful strategy to reduce their flexibility and retard enzymatic degradation. Moreover, these restricted amino acids can stabilize particular conformational features, which may lead to improvements in the biological potency if the bioactive conformation is tethered [14-16].

\section{Results and Discussion Synthesis of new orthopalladated derivatives}

Two phenylglycinate derivatives have been used as starting materials, one of them containing a sterically hindered $\mathrm{N}$ atom, protected by two methyl groups, namely $\left[\mathrm{C}_{6} \mathrm{H}_{5} \mathrm{C}(\mathrm{H})\left(\mathrm{CO}_{2} \mathrm{Me}\right) \mathrm{NMe}_{2}\right][17,18]$, and the other one containing a less hindered, but strongly electron-withdrawing, triflate (Tf) group $\left[\mathrm{C}_{6} \mathrm{H}_{5} \mathrm{C}(\mathrm{H})\left(\mathrm{CO}_{2} \mathrm{Me}\right) \mathrm{NHTf}\right]$ [19]. The orthopalladation of $\left[\mathrm{C}_{6} \mathrm{H}_{5} \mathrm{C}(\mathrm{H})\left(\mathrm{CO}_{2} \mathrm{Me}\right) \mathrm{NMe}_{2}\right]$ has been reported previously by Ryabov and Beck [17,18], and affords complex 1 by heating of $\mathrm{Pd}(\mathrm{OAc})_{2}$ and $\left[\mathrm{C}_{6} \mathrm{H}_{5} \mathrm{C}(\mathrm{H})\left(\mathrm{CO}_{2} \mathrm{Me}\right) \mathrm{NMe}_{2}\right]$ in acetic acid $\left(55-60{ }^{\circ} \mathrm{C}\right.$ over 15-20 $\mathrm{min}$ ), followed by stirring at room temperature for 2-3 days. In this way, complex 1 is obtained in 50\% yield. We did not use this method, and we present here an optimized synthesis of complex $\mathbf{1}$, which is achieved by heating a solution of $\mathrm{Pd}(\mathrm{OAc})_{2}$ with $\left[\mathrm{C}_{6} \mathrm{H}_{5} \mathrm{C}(\mathrm{H})\left(\mathrm{CO}_{2} \mathrm{Me}\right) \mathrm{NMe}_{2}\right](1: 1$ molar ratio $)$ in acetone under reflux for $24 \mathrm{~h}$, followed by the typical metathesis of acetate by chloride bridging ligands in $\mathrm{MeOH}$. Our improved procedure takes place in a shorter reaction time ( 1 versus 3 days) and affords analytically pure complex 1 in yields typically higher than $65 \%$. The characterization of 1 was performed by comparison of its spectral data with those previously reported [18]. On the other hand, the reaction of $\left[\mathrm{C}_{6} \mathrm{H}_{5} \mathrm{C}(\mathrm{H})\left(\mathrm{CO}_{2} \mathrm{Me}\right) \mathrm{NHTf}\right]$ with $\mathrm{Pd}(\mathrm{OAc})_{2}$ (1:1 molar ratio) affords the orthometallated $\left[\mathrm{Pd}(\mu-\mathrm{Cl})\left(\mathrm{C}_{6} \mathrm{H}_{4} \mathrm{CH}\left(\mathrm{CO}_{2} \mathrm{Me}\right) \mathrm{NHTf}-\right.\right.$ $2)]_{2}$ (3), after metathesis of acetate by chloride bridging ligands, as shown in Scheme 2. In this case the reaction also takes place in acetone under reflux, but $48 \mathrm{~h}$ of heating is necessary to achieve completion. Complex $\mathbf{3}$ was characterized following the usual techniques. Both microanalytical and mass spectral data are in good agreement with the proposed dinuclear stoichiometry for $\mathbf{3}$. The ${ }^{1} \mathrm{H}$ NMR spectrum of $\mathbf{3}$ shows broad signals, probably due to different equilibrium processes. These could involve the interconversion between the two possible diastereo-

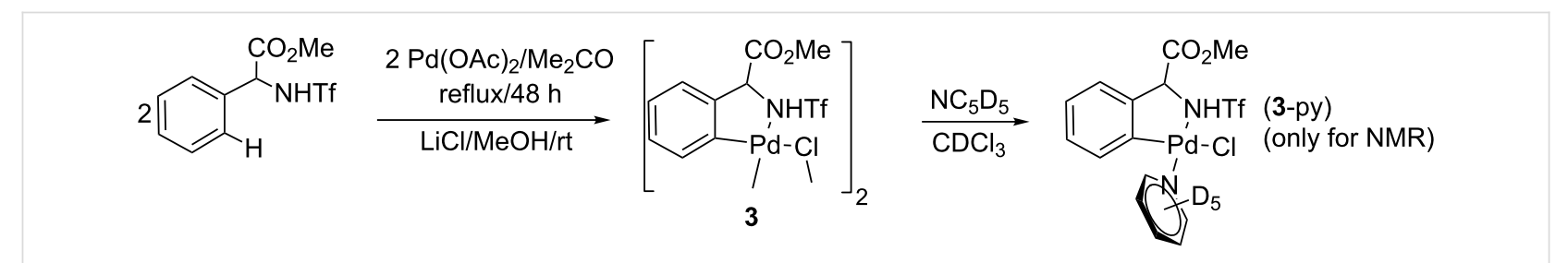


isomers $(R R / S S$ and $R S / S R)$ through cleavage of the chloride bridges, as well as the potential formation of cisoid and transoid geometric isomers. The breakage of the chloride bridging system by $\mathrm{NC}_{5} \mathrm{D}_{5}$ and "in situ" formation of the corresponding mononuclear derivative (3-py, see Scheme 2), which is static on the NMR time scale, simplifies notably the NMR spectra. The ${ }^{1} \mathrm{H}$ NMR spectrum shows then the presence of four well-spread signals, one of them (H6) strongly shifted upfield due to the anisotropic shielding of the cis-pyridine ring. This observation, together with the presence of six different peaks in the ${ }^{13} \mathrm{C}$ NMR spectrum, one of them clearly deshielded $(\mathrm{C} 1$, $151.41 \mathrm{ppm}$ ), points to the presence of the $\mathrm{PdC}_{6} \mathrm{H}_{4}$ unit. All the other features of the NMR data are in keeping with the structure depicted in Scheme 2.

\section{Synthesis of conformationally restricted gluta- mates and glutamines}

Complex 1 reacts with $\mathrm{CO}$ in the presence of alcohols or amines (even aminoesters) affording the corresponding alkoxycarbonylated $(\mathbf{2} \mathbf{a}-\mathbf{f})$ or aminocarbonylated species $(\mathbf{2} \mathbf{g}-\mathbf{j})$, as shown in Scheme 3 and Figure 1, under very mild reaction conditions $\left(\mathrm{CH}_{2} \mathrm{Cl}_{2}, 1 \mathrm{~atm} \mathrm{CO}, 25^{\circ} \mathrm{C}\right)$.

The clear formation of black palladium indicates the progress of the reaction, which is completed typically in $16 \mathrm{~h}$ in all studied cases. After removal of the $\mathrm{Pd}^{0}$ the workup of the reaction is

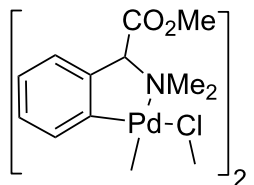

1
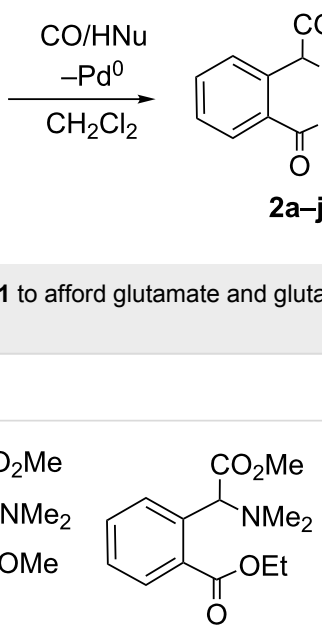

2b $95 \%$<smiles>CC(=O)C(C)c1ccccc1C(=O)Nc1ccccc1</smiles>

2g $59 \%$<smiles>CCOC(=O)c1ccccc1C(=O)C(C)=O</smiles>

2c $38 \%$<smiles>CC(=O)C(C)c1ccccc1C(=O)Nc1ccccc1</smiles>

2h $81 \%$<smiles>CC(=O)OCCO</smiles>

2d $91 \%$<smiles>COC(=O)[C@H](NC(=O)c1ccccc1C(C)C(C)=O)c1ccccc1</smiles>

2i $76 \%$<smiles>COC(=O)c1ccccc1C(C)C(=O)OC</smiles><smiles>CCCCN(C)C(=O)c1ccccc1C(CC)C(C)=O</smiles>

2j $35 \%$

Figure 1: Scope of the carbonylation reaction. 


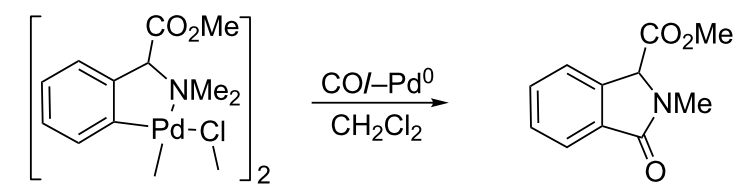

Scheme 4: Reaction of 1 and $\mathrm{CO}$ in $\mathrm{CH}_{2} \mathrm{Cl}_{2}$ [18].

1,2-shift of the Me unit from the $\mathrm{N}$ atom to the Pd centre, as previously reported by Heck et al. [20].

As we have shown previously in Scheme 3, in the presence of nucleophiles the process results in the formation of conformationally restricted glutamate derivatives. This is mainly due to the fact that the demethylation of the $\mathrm{NMe}_{2}$ unit shown in Scheme 4 is not a very favourable process, and the reaction can take a different outcome, especially if alternative pathways are accessible. Taking into account these facts, we can propose a sensible explanation for the different reactivity. Therefore, the attack of the oxygen of an O-bonded alcohol on the electrophilic acyl carbon in our complexes seems to be favoured, since no demethylation is involved, and the $\mathrm{C}-\mathrm{O}$ coupling occurs selectively instead of the intramolecular $\mathrm{C}-\mathrm{N}$ bond formation. It seems that the reaction is driven by the pathway that tends to avoid the demethylation, while the comparison of the different nucleophilic abilities of the species coordinated to the metal (O-bonded alcohols versus $\mathrm{N}$-bonded amines) plays in this case only a minor role.

Using the same arguments we can explain the different reactivity found for $\mathbf{1}$, and shown in Scheme 3, when compared to related Pd complexes previously reported by us [12], resumed in Scheme 1. Therefore, the synthesis of the methyl $(1 H)$-isoindolin-1-one-3-carboxylates by carbonylation of $[\mathrm{Pd}(\mu$ $\left.\mathrm{Cl})\left(\mathrm{C}_{6} \mathrm{H}_{4} \mathrm{CH}\left(\mathrm{CO}_{2} \mathrm{Me}\right) \mathrm{NH}_{2}-2\right)\right]_{2}$ occurs by $\mathrm{C}-\mathrm{N}$ coupling, irrespective of the presence of additional nucleophiles, since the cyclization generates an isoindolinonium salt, from which it is relatively easy to promote a simple deprotonation.

Very interestingly, the reactivity of $\mathbf{1}$ is not limited to the addition of alcohols, and primary amines, secondary amines, and even $\alpha$-aminoesters can also be coupled to the $N, N$-dimethyl- arylglycine fragment, as stated above. Then, the reaction of $\mathbf{1}$ with $\mathrm{CO}$, in $\mathrm{CH}_{2} \mathrm{Cl}_{2}$, and in the presence of stoichiometric amounts of benzylamine, aniline, methyl $(R)$-phenylglycinate or di- $n$-butylamine, occurs with smooth insertion of $\mathrm{CO}$ into the $\mathrm{Pd}-\mathrm{C}_{\text {aryl }}$ bond and further incorporation of the $\mathrm{C}(\mathrm{O}) \mathrm{NHCH}_{2} \mathrm{Ph}$ (2g), $\mathrm{C}(\mathrm{O}) \mathrm{NHPh}(\mathbf{2} \mathbf{h}), \mathrm{C}(\mathrm{O}) \mathrm{NHCH}\left(\mathrm{CO}_{2} \mathrm{Me}\right) \mathrm{Ph}$ (2i) or $\mathrm{C}(\mathrm{O}) \mathrm{NBu}_{2}(\mathbf{2} \mathbf{j})$ moieties into the ortho-position of the $\mathrm{C}_{6} \mathrm{H}_{4} \mathrm{C}(\mathrm{H})\left(\mathrm{CO}_{2} \mathrm{Me}\right) \mathrm{NMe}_{2}$ ligand. This results in the synthesis of the corresponding conformationally restricted glutamines $\mathbf{2 g}-\mathbf{j}$ in moderate to good yields, as shown in Figure 1. This means that the process can be efficiently performed not only with a variety of O-nucleophiles, but also with different types of $\mathrm{N}$-nucleophiles.

In comparison with other aminocarbonylations found in the recent literature [21-24], our method is remarkable since it occurs under very mild reaction conditions ( $1 \mathrm{~atm} \mathrm{CO}, 25^{\circ} \mathrm{C}$ ) and, mainly, because it occurs through $\mathrm{C}-\mathrm{H}$ bond activation processes without the need to use prefunctionalized substrates. Typical aminocarbonylations catalysed by Pd usually start from the corresponding iodides or bromides, and require high $\mathrm{CO}$ pressures and high reaction temperatures. Obviously, further efforts in our systems have to be directed to the transformation of the stoichiometric process into a catalytic one, a challenge that is still not accomplished in the case of the aminocarbonylation, even though several catalytic examples are known of the related alkoxycarbonylation reaction [25-30].

Once we had determined the reactivity of complex 1, having a $N, N$-dimethyl-phenylglycine ligand, we focused our attention on complex $\mathbf{3}$, possessing a triflate as a $N$-protecting group, in order to study the influence of the substituents at the $\mathrm{N}$ atom in the carbonylation further. The reaction of 3 with $\mathrm{CO}(1 \mathrm{~atm})$ in $\mathrm{CH}_{2} \mathrm{Cl}_{2}$ at room temperature, that is, in the absence of nucleophiles, occurs with $\mathrm{C}-\mathrm{N}$ coupling and formation of the methyl 3-oxo-2-((trifluoromethyl)sulfonyl)isoindoline-1-carboxylate (4) in good yields, as shown in Scheme 5 (right).

This means that the $\mathrm{N}$ atom is still nucleophilic enough to promote the cyclization, in spite of the presence of the highly electron-withdrawing triflate group. It is also clear that, after $\mathrm{C}-\mathrm{N}$ coupling, the resulting ammonium salt eliminates easily

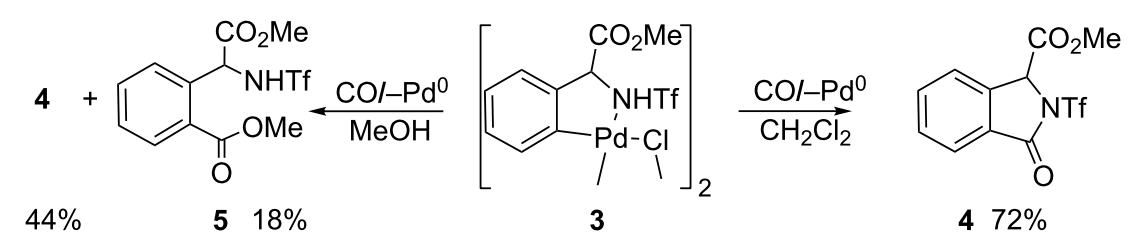

Scheme 5: Reactivity of 3 with CO in the presence (left) and absence (right) of nucleophiles. 
$\mathrm{HCl}$ (formally) affording the neutral amine, in close similarity to the process shown in Scheme 1. However, when the reaction of 3 with $\mathrm{CO}(1 \mathrm{~atm})$ is performed in $\mathrm{MeOH}$, a mixture of the compounds derived from intramolecular cyclization (4) and alkoxycarbonylation (5) is obtained (molar ratio $\mathbf{4} / \mathbf{5}$ 2.4:1). This mixture can be separated by column chromatography, and pure isolated compound $\mathbf{5}$ has been characterized as containing the NHTf group and two different $\mathrm{CO}_{2} \mathrm{Me}$ moieties, as represented in Scheme 5 (left). This result can be interpreted as a competing reaction between the nucleophilic abilities of the $\mathrm{N}$ atom of the glycine moiety and the oxygen atom of the methanol, which in this case is the reaction solvent. It is clear that the introduction of the triflate group decreases the electron density of the $\mathrm{N}$ atom, which is now less nucleophilic in comparison, for example, with the complex containing the $\mathrm{NH}_{2}$ unit, shown in Scheme 1. In that case the $\mathrm{N}$ was quite nucleophilic, and cyclization occurred regardless of the solvent used for the reaction [12]. In the present case the $\mathrm{N}$ is less nucleophilic and competes with other nucleophiles, giving mixtures $\mathbf{4}$ and $\mathbf{5}$ in the presence of methanol. Obviously, in absence of additional nucleophiles, $\mathbf{4}$ is obtained selectively. We attempted several reaction conditions in order to prepare selectively compound $\mathbf{5}$, but it seems to be difficult to quench the intramolecular cyclization, and in all studied cases the 4/5 mixture is obtained. Due to this fact, we have not studied other alcohols.

\section{Conclusion}

The reactivity of the orthopalladated dimers $[\mathrm{Pd}(\mu$ $\left.\mathrm{Cl})\left\{\mathrm{C}_{6} \mathrm{H}_{4}\left(\mathrm{CH}\left(\mathrm{CO}_{2} \mathrm{Me}\right) \mathrm{NR}_{2}\right)-2\right\}\right]_{2}\left(\mathrm{NR}_{2}=\mathrm{NMe}_{2}, \mathrm{NHTf}\right)$ towards $\mathrm{CO}$ in the presence of alcohols or amines as nucleophiles allows for the synthesis of conformationally restricted glutamates or glutamines, respectively, through alkoxycarbonylation or aminocarbonylation intermolecular processes. In spite of the presence of an intramolecular nucleophile (the $\mathrm{N}$ atom of the $\mathrm{NR}_{2}$ group), the formation of the cyclic isoindolinone derivatives has been observed only in one case. This means that the nitrogen atoms of the $\mathrm{NMe}_{2}$ or the NHTf groups behave as weaker nucleophiles than the oxygen or nitrogen atoms of the external nucleophiles involved (alcohols, amines). In addition, the results also show that the nucleophilic abilities of the $\mathrm{N}$ atom in the starting materials $[\mathrm{Pd}(\mu$ $\left.\mathrm{Cl})\left(\mathrm{C}_{6} \mathrm{H}_{4} \mathrm{CH}\left(\mathrm{CO}_{2} \mathrm{Me}\right) \mathrm{NR}_{2}\right)\right]_{2}\left(\mathrm{NR}_{2}=\mathrm{NMe}_{2}, \mathrm{NHTf}\right)$ are weaker than those observed in $\left[\mathrm{Pd}(\mu-\mathrm{Cl})\left(\mathrm{C}_{6} \mathrm{H}_{4} \mathrm{CH}\left(\mathrm{CO}_{2} \mathrm{Me}\right) \mathrm{NH}_{2}\right)\right]_{2}$, for which a systematic intramolecular aminocarbonylation was observed.

\section{Experimental}

General Methods. The general methods are reported in the Supporting Information File 1. The complex $[\operatorname{Pd}(\mu-$ $\left.\mathrm{Cl})\left(\mathrm{C}_{6} \mathrm{H}_{4} \mathrm{CH}\left(\mathrm{CO}_{2} \mathrm{Me}\right) \mathrm{NMe}_{2}-2\right)\right]_{2}$ (1) has been prepared following previously reported procedures $[17,18]$.

\section{Synthesis of methyl N,N-dimethyl-a-(2- methoxycarbonylphenyl)glycinate (2a)}

Methanol (13 $\mu \mathrm{L}, 0.300 \mathrm{mmol})$ was added to a solution of $\mathbf{1}$ (100.0 mg, $0.150 \mathrm{mmol})$ in $\mathrm{CH}_{2} \mathrm{Cl}_{2}(10 \mathrm{~mL})$, and the resulting mixture was stirred under a $\mathrm{CO}$ atmosphere for $16 \mathrm{~h}$. Decomposition to black metallic palladium was observed. The mixture was filtered through a plug of Celite. The light yellow solution was washed with water $(3 \times 20 \mathrm{~mL})$, dried over $\mathrm{MgSO}_{4}$, filtered and evaporated to give compound $\mathbf{2 a}$ as a yellow oil. Yield: $72.9 \mathrm{mg}, 0.290 \mathrm{mmol}, 97 \%$.

${ }^{1} \mathrm{H}$ NMR $\left(300 \mathrm{MHz}, \mathrm{CDCl}_{3}\right) \delta 7.83\left(\mathrm{~d}, J=7.7 \mathrm{~Hz}, 1 \mathrm{H}, \mathrm{C}_{6} \mathrm{H}_{4}\right)$, $7.68\left(\mathrm{~d}, J=7.7 \mathrm{~Hz}, 1 \mathrm{H}, \mathrm{C}_{6} \mathrm{H}_{4}\right), 7.50\left(\mathrm{t}, J=7.7 \mathrm{~Hz}, 1 \mathrm{H}, \mathrm{C}_{6} \mathrm{H}_{4}\right)$, $7.35\left(\mathrm{t}, J=7.7 \mathrm{~Hz}, 1 \mathrm{H}, \mathrm{C}_{6} \mathrm{H}_{4}\right), 5.12(\mathrm{~s}, 1 \mathrm{H}, \mathrm{CH}), 3.89(\mathrm{~s}, 3 \mathrm{H}$, $\mathrm{OMe}), 3.69$ (s, 3H, OMe), $2.31\left(\mathrm{~s}, 6 \mathrm{H}, \mathrm{NMe}_{2}\right) ;{ }^{13} \mathrm{C} \mathrm{NMR}$ $\left(75 \mathrm{MHz}, \mathrm{CDCl}_{3}\right) \delta 172.08(\mathrm{~s}, \mathrm{CO}), 168.36(\mathrm{~s}, \mathrm{CO}), 137.60$ (s, C), $131.96(\mathrm{~s}, \mathrm{CH}), 130.99(\mathrm{~s}, \mathrm{C}), 130.32(\mathrm{~s}, \mathrm{CH}), 129.03(\mathrm{~s}$, $\mathrm{CH}), 127.88(\mathrm{~s}, \mathrm{CH}), 68.42(\mathrm{~s}, \mathrm{CH}), 52.34\left(\mathrm{~s}, \mathrm{OCH}_{3}\right), 51.88(\mathrm{~s}$, $\left.\mathrm{OCH}_{3}\right), 42.97\left(\mathrm{~s}, \mathrm{NMe}_{2}\right)$; IR $\left(v, \mathrm{~cm}^{-1}\right) 1724(\mathrm{C}=\mathrm{O}), 1257$ (C-O); ESIMS (positive mode) $(\mathrm{m} / \mathrm{z}): 251.9[\mathrm{M}+\mathrm{H}]^{+}$; anal. calcd for $\mathrm{C}_{13} \mathrm{H}_{17} \mathrm{NO}_{4}$ (251.12): C, 62.14; H, 6.82; N, 5.57; found: C, 62.35; H, 6.91; N, 5.36.

\section{Synthesis of $[\mathrm{Pd}(\mu-$ $\left.\mathrm{Cl})\left(\mathrm{C}_{6} \mathrm{H}_{4} \mathrm{CH}\left(\mathrm{CO}_{2} \mathrm{Me}\right) \mathrm{NHTf}-2\right)\right]_{2}$ (3)}

To a solution of $\mathrm{Pd}(\mathrm{OAc})_{2}(421.1 \mathrm{mg}, 1.836 \mathrm{mmol})$ in acetone (30 mL), PhCH(CO $\left.{ }_{2} \mathrm{Me}\right)$ NHTf [19] (545.8 mg, $\left.1.836 \mathrm{mmol}\right)$ was added, and the resulting mixture was heated under reflux for $48 \mathrm{~h}$. After the reaction time, the solution was evaporated to dryness, the residue was treated with $\mathrm{CH}_{2} \mathrm{Cl}_{2}(40 \mathrm{~mL})$, and the resulting suspension was filtered over a Celite pad. The resulting clear solution was again evaporated to dryness, and the residue was dissolved in $\mathrm{MeOH}$ and allowed to react with $\mathrm{NaCl}$ (243.6 mg, $4.167 \mathrm{mmol}$ ) at room temperature for $4 \mathrm{~h}$. The pale yellow solution was evaporated to dryness, the dry residue extracted with $\mathrm{CH}_{2} \mathrm{Cl}_{2}(30 \mathrm{~mL})$, and the resulting suspension filtered to eliminate the excess of $\mathrm{NaCl}$. Evaporation of this clear solution and treatment of the residue with pentane afforded $\mathbf{3}$ as a yellow-brownish solid. Yield: $452.6 \mathrm{mg}$, $0.516 \mathrm{mmol}, 56.2 \%$ yield.

${ }^{1} \mathrm{H}$ NMR $\left(300 \mathrm{MHz}, \mathrm{CDCl}_{3}+\mathrm{py}-d_{5}\right) \delta 7.21(\mathrm{dd}, J=7.6$, $\left.1.5 \mathrm{~Hz}, 1 \mathrm{H}, \mathrm{C}_{6} \mathrm{H}_{4}\right), 6.94\left(\mathrm{td}, J=7.4,1.2 \mathrm{~Hz}, 1 \mathrm{H}, \mathrm{C}_{6} \mathrm{H}_{4}\right), 6.71$ $\left(\mathrm{td}, J=7.5,1.5 \mathrm{~Hz}, 1 \mathrm{H}, \mathrm{C}_{6} \mathrm{H}_{4}\right), 5.91(\mathrm{dd}, J=7.7,1.2 \mathrm{~Hz}, 1 \mathrm{H}$, $\left.\mathrm{C}_{6} \mathrm{H}_{4}\right), 5.38(\mathrm{~s}, 1 \mathrm{H}, \mathrm{CH}), 3.78\left(\mathrm{~s}, 3 \mathrm{H}, \mathrm{OCH}_{3}\right), 2.24(\mathrm{~s}, 1 \mathrm{H}, \mathrm{NH})$; ${ }^{13} \mathrm{C} \mathrm{NMR}\left(75 \mathrm{MHz}, \mathrm{CDCl}_{3}+\right.$ py- $\left.d_{5}\right) \delta 173.94(\mathrm{~s}, \mathrm{CO}), 151.41(\mathrm{~s}$, $\left.\mathrm{C}, \mathrm{C}_{6} \mathrm{H}_{4}\right), 149.54(\mathrm{~m}, \mathrm{CD}, \mathrm{py}), 146.10\left(\mathrm{~s}, \mathrm{C}, \mathrm{C}_{6} \mathrm{H}_{4}\right), 135.55(\mathrm{~m}$, $\mathrm{CD}, \mathrm{py}), 132.49$ (s, CH, $\left.\mathrm{C}_{6} \mathrm{H}_{4}\right), 125.57$ (s, CH, $\left.\mathrm{C}_{6} \mathrm{H}_{4}\right), 124.46$ (s, $\mathrm{CH}, \mathrm{C}_{6} \mathrm{H}_{4}$ ), 123.29 (m, CD, py), 122.69 (s, CH, $\mathrm{C}_{6} \mathrm{H}_{4}$ ), 120.82 (q, $\left.J=324.6 \mathrm{~Hz}, \mathrm{CF}_{3}\right), 72.37$ (s, $\left.\mathrm{CH}\right), 52.30\left(\mathrm{~s}, \mathrm{OCH}_{3}\right)$; ${ }^{19} \mathrm{~F}$ NMR $\left(282 \mathrm{MHz}, \mathrm{CDCl}_{3}+\right.$ py- $\left.d_{5}\right) \delta-76.71\left(\mathrm{~s}, \mathrm{CF}_{3}\right)$; IR $(v$, 
$\mathrm{cm}^{-1}$ ): 3375 (br, N-H), 1742 (vCOO); ESIMS (positive mode) $(m / z): 439[\mathrm{M} / 2+\mathrm{H}]^{+}$; anal. calcd for $\mathrm{C}_{20} \mathrm{H}_{18} \mathrm{Cl}_{2} \mathrm{~F}_{6} \mathrm{~N}_{2} \mathrm{O}_{8} \mathrm{Pd}_{2} \mathrm{~S}_{2}$ (876.23): C, 27.41; H, 2.07; N, 3.20; S, 7.32; found: C, 26.93; H, 2.02; N, 3.45; S, 6.98 .

\section{Synthesis of methyl 3-oxo-2- ((trifluoromethyl)sulfonyl)isoindoline-1- carboxylate (4)}

A solution of $3(50.0 \mathrm{mg}, 0.057 \mathrm{mmol})$ in dichloromethane was stirred under a CO atmosphere for $16 \mathrm{~h}$. Decomposition to black palladium was observed. The mixture was filtered through a plug of Celite, and the yellow solution was washed with water $(3 \times 20 \mathrm{~mL})$, dried over $\mathrm{MgSO}_{4}$, filtered and evaporated to give 4 as a yellow oil. Yield: $26.7 \mathrm{mg}, 0.083 \mathrm{mmol}, 72 \%$.

${ }^{1} \mathrm{H}$ NMR $\left(300 \mathrm{MHz}, \mathrm{CDCl}_{3}\right) \delta 7.98(\mathrm{dt}, J=7.7,1.0 \mathrm{~Hz}, 1 \mathrm{H}$, $\left.\mathrm{C}_{6} \mathrm{H}_{4}\right), 7.79\left(\mathrm{td}, J=7.6,1.2 \mathrm{~Hz}, 1 \mathrm{H}, \mathrm{C}_{6} \mathrm{H}_{4}\right), 7.68(\mathrm{dd}, J=7.8$, $\left.0.9 \mathrm{~Hz}, 1 \mathrm{H}, \mathrm{C}_{6} \mathrm{H}_{4}\right), 7.65\left(\mathrm{td}, J=7.5,0.7 \mathrm{~Hz}, 1 \mathrm{H}, \mathrm{C}_{6} \mathrm{H}_{4}\right), 5.72(\mathrm{~s}$, $1 \mathrm{H}, \mathrm{CH}), 3.85\left(\mathrm{~s}, 3 \mathrm{H}, \mathrm{OCH}_{3}\right) ;{ }^{13} \mathrm{C} \mathrm{NMR}\left(75 \mathrm{MHz}, \mathrm{CDCl}_{3}\right) \delta$ 166.65 (s, CO), 164.37 (s, CO), 139.43 (s, C), 135.84 (s, CH), 130.87 (s, CH), 127.63 (s, C), 126.49 (s, CH), 123.54 (s, CH), 119.59 (q, $\left.J=323.5 \mathrm{~Hz}, \mathrm{CF}_{3}\right), 63.20(\mathrm{~s}, \mathrm{CH}), 53.94\left(\mathrm{~s}, \mathrm{OCH}_{3}\right)$; ${ }^{19} \mathrm{~F}$ NMR $\left(282 \mathrm{MHz}, \mathrm{CDCl}_{3}\right) \delta-74.04\left(\mathrm{~s}, \mathrm{CF}_{3}\right)$; IR $\left(v, \mathrm{~cm}^{-1}\right)$ : 1758 (COO). ESIMS (positive mode) $(\mathrm{m} / \mathrm{z}): 324.0[\mathrm{M}+\mathrm{H}]^{+}$; anal. calcd for $\mathrm{C}_{11} \mathrm{H}_{8} \mathrm{~F}_{3} \mathrm{NO}_{5} \mathrm{~S}$ (323.01): C, 40.87; H, 2.49; N, 4.33; S, 9.92; found: C, 40.94; H, 2.53; N, 4.41; S, 10.05 .

\section{Synthesis of methyl $N$-trifluoromethylsulfon- amido- $\alpha-(2-m e t h o x y c a r b o n y l p h e n y l) g l y c i-$ nate (5)}

A solution of 3 (100.0 mg, $0.114 \mathrm{mmol})$ in methanol was stirred under a $\mathrm{CO}$ atmosphere for $16 \mathrm{~h}$. During the reaction, the formation of $\mathrm{Pd}^{0}$ was evident. The black material was eliminated by filtration through a plug of Celite, and the resulting light yellow solution was washed with water $(3 \times 20 \mathrm{~mL})$, dried over $\mathrm{MgSO}_{4}$, filtered and evaporated to give an oily residue characterized as the mixture of compounds $\mathbf{4}$ and $\mathbf{5}$. This mixture was separated by column chromatography (silica, hexane $/ \mathrm{CH}_{2} \mathrm{Cl}_{2}$ : 3/7), yielding pure 5 as a colourless oil. Yield: $14.2 \mathrm{mg}$, $0.040 \mathrm{mmol}, 18 \%$.

${ }^{1} \mathrm{H}$ NMR $\left(300 \mathrm{MHz}, \mathrm{CDCl}_{3}\right) \delta 8.10(\mathrm{dd}, J=7.8,1.5 \mathrm{~Hz}, 1 \mathrm{H}$, $\left.\mathrm{C}_{6} \mathrm{H}_{4}\right), 7.61\left(\mathrm{td}, J=7.5,1.5 \mathrm{~Hz}, 1 \mathrm{H}, \mathrm{C}_{6} \mathrm{H}_{4}\right), 7.50(\mathrm{td}, J=7.6$, $\left.1.4 \mathrm{~Hz}, 1 \mathrm{H}, \mathrm{C}_{6} \mathrm{H}_{4}\right), 7.41\left(\mathrm{dd}, J=7.6,1.5 \mathrm{~Hz}, 1 \mathrm{H}, \mathrm{C}_{6} \mathrm{H}_{4}\right), 7.00$ $(\mathrm{d}, J=9.4 \mathrm{~Hz}, 1 \mathrm{H}, \mathrm{NH}), 5.42(\mathrm{~d}, J=9.3 \mathrm{~Hz}, 1 \mathrm{H}, \mathrm{CH}), 3.92$ (s, $\left.3 \mathrm{H}, \mathrm{OCH}_{3}\right), 3.75\left(\mathrm{~s}, 3 \mathrm{H}, \mathrm{OCH}_{3}\right) ;{ }^{13} \mathrm{C} \mathrm{NMR}\left(75 \mathrm{MHz}, \mathrm{CDCl}_{3}\right) \delta$ 168.89 (s, CO), 168.43 (s, CO), 137.53 (s, C), 133.86 (s, C), 132.59 (s, CH), 132.01 (s, CH), $129.68(\mathrm{~s}, \mathrm{CH}), 127.30(\mathrm{~s}, \mathrm{CH})$, 119.53 (q, $\left.J=320.7 \mathrm{~Hz}, \mathrm{CF}_{3}\right), 61.35(\mathrm{~s}, \mathrm{CH}), 53.42\left(\mathrm{~s}, \mathrm{OCH}_{3}\right)$, $53.03\left(\mathrm{~s}, \mathrm{OCH}_{3}\right) ;{ }^{19} \mathrm{~F}$ NMR $\left(282 \mathrm{MHz}, \mathrm{CDCl}_{3}\right) \delta-77.53(\mathrm{~s}$, $\mathrm{CF}_{3}$ ); IR (v, $\mathrm{cm}^{-1}$ ): 3282 (br, N-H), 1747 (COO), 1711 (COO);
ESIMS (positive mode) $(\mathrm{m} / \mathrm{z}): 324.2[\mathrm{M}-\mathrm{OMe}]^{+}, 356.0[\mathrm{M}+$ $\mathrm{H}]^{+}$; anal. calcd for $\mathrm{C}_{12} \mathrm{H}_{12} \mathrm{~F}_{3} \mathrm{NO}_{6} \mathrm{~S}$ (355.03): C, 40.57; H, 3.40; N, 3.94; S, 9.03; found: C, 40.42; H, 3.24; N, 3.82; S, 8.93.

\section{Supporting Information}

\section{Supporting Information File 1}

General methods and experimental and analytical data of compounds $\mathbf{2 b}-\mathbf{j}$.

[http://www.beilstein-journals.org/bjoc/content/

supplementary/1860-5397-8-179-S1.pdf]

\section{Acknowledgements}

Financial support from the Spanish Ministerio de Economía y Competitividad (projects CTQ2011-22589 and CTQ2010-17436) and Gobierno de Aragón (Spain, research groups E97 and E40) is gratefully acknowledged. E. L. thanks Gobierno de Aragón (Spain) for a $\mathrm{PhD}$ grant (reference B008/10).

\section{References}

1. Yu, J.-Q.; Shi, Z., Eds. Top. Curr. Chem.; 2010; Vol. 292, pp 1-379. doi:10.1007/978-3-642-12356-6

2. Davies, H. M. L.; Du Bois, J.; Yu, J.-Q. Chem. Soc. Rev. 2011, 40, 1845-2039. doi:10.1039/c1cs90010b

3. Simmons, E. M.; Hartwig, J. F. Nature 2012, 483, 70-73. doi:10.1038/nature 10785

4. Lyons, T. W.; Sanford, M. S. Chem. Rev. 2010, 110, 1147-1169. doi:10.1021/cr900184e

5. Yeung, C. S.; Dong, V. M. Chem. Rev. 2011, 111, 1215-1292. doi:10.1021/cr100280d

6. Le Bras, J.; Muzart, J. Chem. Rev. 2011, 111, 1170-1214. doi:10.1021/cr100209d

7. You, S.-L.; Xia, J.-B. Top. Curr. Chem. 2010, 292, 165-194. doi:10.1007/128_2009_18

8. Yoo, W.-J.; Li, C.-J. Top. Curr. Chem. 2010, 292, 281-302. doi:10.1007/128_2009_17

9. Newhouse, T.; Baran, P. S. Angew. Chem., Int. Ed. 2011, 50, 3362-3374. doi:10.1002/anie.201006368

10. Aguilar, D.; Cuesta, L.; Nieto, S.; Serrano, E.; Urriolabeitia, E. P. Curr. Org. Chem. 2011, 15, 3441-3464. doi:10.2174/138527211797247923

11. Nieto, S.; Arnau, P.; Serrano, E.; Navarro, R.; Soler, T.; Cativiela, C.; Urriolabeitia, E. P. Inorg. Chem. 2009, 48, 11963-11975. doi:10.1021/ic901941s

12. Nieto, S.; Sayago, F. J.; Laborda, P.; Soler, T.; Cativiela, C.; Urriolabeitia, E. P. Tetrahedron 2011, 67, 4185-4191. doi:10.1016/j.tet.2011.04.064

13. Nieto, S.; Cativiela, C.; Urriolabeitia, E. P. New J. Chem. 2012, 36, 566-569. doi:10.1039/c2nj20909h

14. Cowell, S. M.; Lee, Y. S.; Cain, J. P.; Hruby, V. J. Curr. Med. Chem. 2004, 11, 2785-2798. doi:10.2174/0929867043364270

15. Toniolo, C.; Crisma, M.; Formaggio, F.; Peggion, C. Biopolymers 2001, $60,396-419$. doi:10.1002/1097-0282(2001)60:6<396::AID-BIP10184>3.0.CO;2-7 
16. Sagan, S.; Karoyan, P.; Lequin, O.; Chassaing, G.; Lavielle, S. Curr. Med. Chem. 2004, 11, 2799-2822.

doi:10.2174/0929867043364108

17. Ryabov, A. D.; Polyakov, V. A.; Yatsimirski, A. K. Inorg. Chim. Acta 1984, 91, 59-65. doi:10.1016/S0020-1693(00)84220-6

18. Böhm, A.; Polborn, K.; Sünkel, K.; Beck, W. Z. Naturforsch. 1998, 53b, 448-458.

19. Hendrickson, J. B.; Bergeron, R.; Sternbach, D. D. Tetrahedron 1975, 31, 2517-2521. doi:10.1016/0040-4020(75)80263-8

20. Thompson, J. M.; Heck, R. F. J. Org. Chem. 1975, 40, 2667-2674. doi:10.1021/jo00906a021

21. Wu, X.-F.; Schranck, J.; Neumann, H.; Beller, M. ChemCatChem 2012, 4, 69-71. doi:10.1002/cctc.201100268

22. Wu, X.-F.; Neumann, H.; Beller, M. Chem.-Eur. J. 2010, 16 , 9750-9753. doi:10.1002/chem.201000090

23. Dang, T. T.; Zhu, Y.; Ghosh, S. C.; Chen, A.; Chai, C. L. L.; Seayad, A. M. Chem. Commun. 2012, 48, 1805-1807. doi:10.1039/c2cc16808a

24. Sawant, D. N.; Wagh, Y. S.; Bhatte, K. D.; Bhanage, B. M. J. Org. Chem. 2011, 76, 5489-5494. doi:10.1021/jo200754v

25. Houlden, C. E.; Hutchby, M.; Bailey, C. D.; Gair Ford, J.; Tyler, S. N. G.; Gagné, M. R.; Lloyd-Jones, G. C.; Booker-Milburn, K. I. Angew. Chem., Int. Ed. 2009, 48, 1830-1833. doi:10.1002/anie.200805842

26. Yoo, E. J.; Wasa, M.; Yu, J.-Q. J. Am. Chem. Soc. 2010, 132, 17378-17380. doi:10.1021/ja108754f

27. Giri, R.; Lam, J. K.; Yu, J.-Q. J. Am. Chem. Soc. 2010, 132, 686-693. doi:10.1021/ja9077705

28. Wu, X.-F.; Anbarasan, P.; Neumann, H.; Beller, M. Angew. Chem., Int. Ed. 2010, 49, 7316-7319. doi:10.1002/anie.201003895

29. Yu, W.-Y.; Sit, W. N.; Lai, K.-M.; Zhou, Z.; Chan, A. S. C. J. Am. Chem. Soc. 2008, 130, 3304-3306. doi:10.1021/ja710555g

30. Xie, P.; Xie, Y.; Qian, B.; Zhou, H.; Xia, C.; Huang, H. J. Am. Chem. Soc. 2012, 134, 9902-9905. doi:10.1021/ja3036459

\section{License and Terms}

This is an Open Access article under the terms of the Creative Commons Attribution License (http://creativecommons.org/licenses/by/2.0), which permits unrestricted use, distribution, and reproduction in any medium, provided the original work is properly cited.

The license is subject to the Beilstein Journal of Organic Chemistry terms and conditions:

(http://www.beilstein-journals.org/bjoc)

The definitive version of this article is the electronic one which can be found at: $\underline{\text { doi: } 10.3762 / \text { bjoc. } 8.179}$ 